\title{
RETHINKING THE POLITICS OF WHITE ETHNICITY IN 1970s AMERICA
}

\author{
DR JOE MERTON \\ University of Nottingham
}

\section{RETHINKING THE POLITICS OF WHITE ETHNICITY}

\begin{abstract}
Historians have tended to characterize the 'white ethnic' identity politics of the 1970s in the United States as a significant feature of the conservative counterrevolution, especially the rise of populist racial conservatism and its splintering of the Democratic New Deal coalition. Seeking to provide a broader, more representative portrait of white ethnic mobilization, activism, and institutionalization in government, with particular focus on the work of Rev. Geno Baroni, the National Center for Urban Ethnic Affairs, and the Carter administration's Office of Ethnic Affairs, this article challenges that assumption. It posits that the politics of white ethnicity was a far more complex, diverse phenomenon, of appeal to liberals and conservatives in an era of considerable political flux. This reconsideration also reveals that the 1970s were not conservative in the United States, but a watershed decade of uncertainty, volatility, and experimentation, in which ethnic identities and affiliations were reshaped, political norms upended, and new forms of organization and mobilization trialled out, with great significance for today's 'post-ethnic' United States. White ethnic politics was of considerable importance to American political development in the late twentieth century, but not in the way usually thought.
\end{abstract}

Standing in the Roosevelt Room of the White House in April 1977, the stocky Catholic priest tugged at his white collar and smiled nervously. He had been sworn in as Assistant Secretary for Neighborhoods at the Department of Housing \& Urban Development (HUD), serving under the new Democratic president, Jimmy Carter. The priest's proud 


\section{JOE MERTON}

immigrant parents stood to his right; Vice President Walter Mondale, presiding, to his left. Above this avowedly 'ethnic' Italian-American priest hung a portrait of President Theodore Roosevelt, who only sixty years earlier had warned of the 'menace' posed by hyphenated Americans, demanding ‘100 percent Americanism’.

For the Rev. Geno Baroni, this was the culmination of a decade's work as a national advocate for the 'white ethnics' - the mainly working-class descendants of Southern and Eastern European immigrants. In contrast to Roosevelt, he encouraged these groups to reject assimilation and assert a new 'white ethnic' identity, analogous to racial minorities, emphasising themes of ethnic disadvantage, discrimination, and group difference to gain material and psychological reward. Rather than organize ethnic whites along individual national-group lines, Baroni sought to build a unified, multiethnic political culture and identity under this new label that would transcend differences of language, religion and national origin. Observers anticipated that Baroni’s appointment marked the beginning of a concerted federal effort to address a white ethnic agenda similar to that of its black or Hispanic antecedents. ${ }^{1}$

What exactly constituted this white ethnic agenda was not always clear or consistent. Whereas some advocates thought in terms of socio-economic disadvantage, hypothesising the white ethnics as an underprivileged, needy minority group, others focused on cultural concerns, addressing a perceived sense of cultural inferiority, even discrimination. Both spoke to a lingering sense of ethnic anxiety, unease, and disillusionment with traditional political and cultural norms at the beginning of the 1970s. The result was an unwieldy, sometimes contradictory agenda which reflected the diversity of the white ethnic constituency, and also hinted at potential obstacles to group 


\section{THE POLITICS OF WHITE ETHNICITY}

cohesion and future policy breakthroughs for their number, but which also reflected a transformed post-civil rights political environment in which group identities, rights claims and mobilization were crucial, and the volatile and uncertain tenor of the times.

Baroni recognized the necessity of responding to this political shift. A Catholic

minister in the Pennsylvania coalfields and then Washington D.C., Baroni had worked for anti-poverty and civil rights causes before being appointed in 1966 to head a Catholic church task force on urban problems, through which he became acquainted with the difficulties facing working-class whites. Four years later, Baroni came to national attention after using the Catholic Bishops' Labor Day statement to reject the 'widespread accusation [urban ethnics are]... the primary exponents of racism in our society', instead citing the neglect and poverty they faced. Baroni urged the inclusion of ethnic whites alongside racial minorities in programmes designed to address the urban crisis, alleviating what he saw as an alarming trend towards group conflict and polarization:

Little attention has been given to the anguish of the... ethnic "forgotten" American... there is a desperate need to reduce and prevent the confrontation... between the white urban ethnic groups and the minority poor... We must go beyond the civil rights struggle of the $60 \mathrm{~s} .$. We must bring together a new coalition... the blacks, the Appalachians, the Indians, the Spanish-speaking, and the white urban ethnic groups... then we can develop a true cultural pluralism in this country and reduce... group conflict. ${ }^{2}$ 
JOE MERTON

Calling for a 'new urban populism' that would bring 'urban ethnics' together with racial minorities on issues of mutual interest, he sought to alleviate racial tensions and restore the liberal coalition. He looked to black Americans as a role model, not as a rival, adopting their techniques and vocabulary. 'Those of us in the ethnic bag', he confessed, 'can learn from the blacks about the importance of cultural identity.' ${ }^{3}$ By emphasizing ethnicity over race, class or national origin, Baroni offered a new means of reaching out to disaffected working-class whites who felt they had been left behind by the pace of liberal social change during the 1960s, and his influence grew. A six-page interview in the Washington Post in 1969 asked, 'Is he [Baroni] one of the few relevant white men in this city?"4

In the political world of the 1970s, Baroni was extremely successful in articulating a variety of competing white ethnic concerns. The expansion of federal social policies would ease the socio-economic disadvantages felt by white ethnic Americans. Neighbourhood revitalization programmes for ethnic communities, he declared, would rejuvenate the blighted urban areas in which they lived. Ethnic studies courses would alleviate ethnics' cultural inferiority and breed group understanding. Affirmative action and quotas would correct the discrimination long faced by ethnic Americans. Each was instituted by local, state and federal governments during the 1970s. Baroni's National Center for Urban Ethnic Affairs (NCUEA) secured funding from organizations ranging from the Ford Foundation and the US Catholic Conference to the White House. His conferences on white ethnic issues attracted high-profile press coverage and academics, community leaders and politicians with national ambitions. Baroni’s prominence in public affairs gave the impression of a movement on the rise. 


\section{THE POLITICS OF WHITE ETHNICITY}

Baroni was also a regular visitor to the White House. In the summer of 1970, he met with President Nixon, who underscored his support for the new affirmation of white ethnicity and his sensitivity to ethnics' social problems. ${ }^{5}$ In 1976 , Baroni returned to the White House to broker four conferences, with the new White House Office of Ethnic Affairs, on ethnicity and public policy. And in that year's presidential election, Baroni was a senior adviser to Carter's Democratic campaign. His reward for his work - which Carter aides acknowledged 'turned us around with the Catholic voters' - was his HUD appointment. $^{6}$

Despite the potential contradictions of the 'white ethnic' agenda, Baroni's efforts initially worked well in the transformed post-civil rights political environment of the 1970s. And Baroni was by no means a lone voice in developing a more temperate white ethnic politics. This cadre called for urban reinvestment and community activism, the expansion rather than the retrenchment of the Great Society reforms of the 1960s, and racial cooperation rather than backlash. They laid claim to new federal programmes, funds, rights and entitlements for minority groups. They developed new models of multiculturalism and Americanism, looked to rejuvenate liberalism, and sought to build multiracial coalitions. Such a politics was far removed from images of anti-busing protesters in Boston, hard-hats in New York City, or stone-throwing mobs in Cicero, Illinois; the traditional symbols of white ethnic politics. Instead, Barbara Mikulski of Baltimore, Stephen Adubato of Newark, Baroni: these were the real faces of 'Ethnic Power', as Newsweek dubbed it in 1970, 'the newest rallying cry in American politics'.7 


\section{JOE MERTON}

\section{I}

This evidence is largely absent from historical narratives of the white ethnics. Instead, the white ethnic upsurge of the 1970s is often viewed through one of two rather limiting lenses. On the one hand, some have written of an ethnic 'revival' or 'reawakening', an era in which the cultural manifestations of white, European ethnicity reasserted themselves. ${ }^{8}$ From Hollywood films to novelty license plates, national cuisine to its favourite TV shows, American culture discredited assimilatory, melting pot ideals in favour of the assertion of ethnicity during the 1970s. This was the era of Roots, The Godfather and the Prince Spaghetti commercials, 'It's Great to be Greek' buttons and 'Visit Your Homeland' tour packages - commodified, almost trivialized interpretations of ethnicity.

On the other, many works touching on white ethnic politics have focused on images of angry, marginalized whites, resentful of the socio-economic progress of blacks and the establishment liberals who championed their cause. The words of the National Confederation of American Ethnic Groups' Paul Deac sound a familiar refrain in the historiography on white ethnicity: 'We spend millions and the Negroes get everything and we get nothing.'9

So why are the more progressive, substantive manifestations of white ethnic politics - equally, if not more prominent during the period - overlooked in favour of images of 'Kiss Me I'm Italian' buttons or resentful whites? Historians have moved towards a more nuanced appreciation of the African-American and Chicano rights movements of the second half of the twentieth century, underlining the many cleavages, 


\section{THE POLITICS OF WHITE ETHNICITY}

interests, and divisions within each community. Why have they not done likewise for the white ethnics?

The answer may lie in the tendency in the literature to render the white ethnic upsurge inseparable from the rise of populist racial conservatism during the 1970s. In this interpretation, these angry ethnics were the harbinger of a conservative backlash against Democratic liberalism in the urban north, 'reactionary populists' who broke from their Democratic moorings to vote for George Wallace, protested school busing and affirmative action, and formed the vanguard of Nixon's 'Silent Majority'. They were the prototypical Reagan Democrats - the working and middle-class whites who deserted the party of Roosevelt for the party of Reagan. Their affirmation of their ethnicity and defence of old neighbourhoods and traditions served only as a politically palatable Trojan horse for what sociologist Orlando Patterson described as 'covert anti-black political action', a means of perpetuating white racial primacy in the urban north in response to black migration, the civil rights movement and the legislation that responded to it. ${ }^{10}$

Consequently, scholars have established - and continue to reinforce - a causal link between the politics of white ethnicity and the rise of racial conservatism in the collapse of the New Deal coalition. Mary Waters accuses the ethnic politics of the 1970s of 'fanning the flames of racial division', much to conservatives' long-term gain. Matthew Jacobson has tied together 'ethnic reverie' and 'conservative rebirth', demonstrating how conservatives co-opted the rhetorical symbols and motifs of the politics of white ethnicity - so-called 'ethnic values' of self-reliance and hard work - to assail racially redistributive public policies. Robert Mason has identified the white ethnics as a core constituency of Richard Nixon's 'New Majority' project; their votes 
JOE MERTON

pursued, and secured, through an 'opposition to racial liberalism'. Finally, John Skrentny and Thomas Sugrue have revealed how conservatives constructed a 'smashingly successful' political majority through engagement with the politics of white ethnicity. For Sugrue and Skrentny, the white ethnics were 'the embodiment of Nixon's Silent Majority... alienated by the civil rights movement, betrayed by liberals, and simmering with "middle-class rage". Their analysis of Nixon's divisive politics of ethnic ressentiment even forms a chapter in an edited collection entitled Rightward bound: making America conservative in the 1970s. ${ }^{11}$

But have we got this wrong? If white ethnic politics was an expression of white racial privilege and conservatism, as so many scholars suggest, why did ethnic groups rediscover their minority status and identity during the 1970s? Why did they resurrect earlier, pejorative, images of themselves as 'not quite white', and build coalitions with minority groups rather than whites? ${ }^{12}$ In our focus on the more visceral, extreme expressions of white ethnicity, or our desire to look for linear trends and clearly-defined meanings in this political moment, have we overlooked the manifestations of white ethnic political activity that were neither reactionary or racially conservative? Was there a liberal alternative wrapped up in the white ethnic politics of the 1970s ${ }^{13}$

This article will argue that we should reconsider what we know about the politics of white ethnicity, and what we consider to be its broader significance. By overlooking the work of Baroni et al in favour of themes of conservative resistance and racial populism, historians have failed to appreciate the complexity of the politics of white ethnicity and left us unenlightened as to the influence it held over progressive politics during the 1970s. Not only that, but they have overstated its importance to political 


\section{THE POLITICS OF WHITE ETHNICITY}

change in the latter part of the twentieth century. The story of the white ethnic political activism of the 1970s does not fit easily into a teleological liberal-conservative narrative, but is deeply contested and diverse. White ethnicity was of appeal to actors of all stripes, and each used it as a means to build new political coalitions and new visions of national identity and community. By working towards a fuller understanding of both the content and the impulses behind white ethnic activism, shaped more by the breakthroughs of the civil rights movements of the 1960s than any nascent conservatism, we can realize the extent of its influence over political development during the 1970s, and probe the wider meaning of this volatile chapter in American political life.

\section{II}

'[A] revolution is taking place in white working-class communities of Northeastern and Midwestern Urban America', an aide to New York mayor John Lindsay observed upon attending an NCUEA conference in June 1971. 'The Melting Pot myth is dead and buried... alienation, frustration, lack of identity and lack of upward mobility have forced them to the wall. They are now ready to fight for power.' ${ }^{14}$ The aide was responding to the political mobilization of European ethnic groups from across the industrial northeast and midwest. Activists and community organizers responded to the transformed exogenous environment of the late 1960s and early 1970s and developed a network of national and grassroots organizations to push white ethnic group interests in local politics and on the national stage. 'White, middle America ethnics will set the agenda for the 1970s', one activist proclaimed in 1972. 'We are all ethnics now', concluded the ItaloAmerican Times in the same year. ${ }^{15}$ 
The emergence of this world of white ethnic mobilization, assertion, and activism was unexpected. In the two decades following the Second World War, white ethnic identities had appeared largely superfluous to national political life, transcended by the myth of the American melting pot, a faith in upward mobility and a sense of political consensus, even conformity. Sociologists concluded that identities of race and religion had subsumed those of ethnicity and national origin, and national politics was no exception. 'Appeals centred on... the ethnic melting pot', political scientist Walter Dean Burnham declared in the early 1960s, '[are] almost as archaic as appeals to Civil War loyalties.' 16

However, the reassertion of ethnic identity reflected the transformed political environment of the late 1960s and 1970s United States. The liberal consensus and its values of assimilation, universalism, and individual rights and opportunity had imploded. Liberalism's attentiveness towards racial minorities, asking the white working and middle-class to bear the cost of programmes of relief and redress for these groups in an inflationary economy, stoked ethnic anger, alienation and a fear of being forgotten. However, these feelings did not necessarily translate themselves into racial backlash. Instead, electoral turnout plummeted in ethnic wards, and Polish-Americans and ItalianAmericans rated highly for feelings of fear, anomie, and alienation. ${ }^{17}$ Such an uncertain environment left behind a political vacuum that defined the new epoch, providing the space in which white ethnic organizations and institutions could mobilize and evolve.

This sense of vacuum was further underlined by the decline of traditional political institutions or means of coalition-building, such as the urban Democratic machines, and the eclipse of an old distributional politics of economic need by new ethno-cultural 


\section{THE POLITICS OF WHITE ETHNICITY}

concerns such as race, crime, and morality. ${ }^{18}$ In ethnic communities fraternal orders and parish organizations were increasingly anachronistic institutions. ${ }^{19}$ White ethnic activists and organizations sought to fill the void. In 1974, Baroni observed that, '[the] organizations traditionally serving these communities - the Catholic church, the unions, the Democratic Party - have lost their ability... to address the real needs of these communities', and emphasized the role the NCUEA could play in replacing them. ${ }^{20}$

Meanwhile, the staggering impact of the Black Power template encouraged many groups to seek recognition and recompense in a polity increasingly conscious of group rights. Whilst ethnic defensiveness and resentment towards Black Power was undoubtedly a trigger for the new politics of white ethnicity, it also acted, paradoxically, as an inspiration to many ethnic activists. Blacks' success in securing community control of services, electing political candidates and building respect for their cultural identity made their model an alluring one, demonstrating how group identities could be used as a means of political mobilization and securing rewards from government.

Perhaps most important in the crystallization of white ethnic group assertion was a new politics of group rights and compensatory justice - what John Skrentny has dubbed 'the minority rights revolution' - which emerged in the wake of the black political protest

of the 1960s. ${ }^{21}$ Previously, civil rights advocacy organizations such as the NAACP, G.I. Forum, and LULAC had pursued their goals by emphasising themes of integration, citizenship and above all their fundamental similarity to the American majority (even, in some cases, their whiteness). Once these ends were reached, it was assumed that ethnoracial labels and distinctions would disappear. ${ }^{22}$ 


\section{JOE MERTON}

However, by the 1970s the rules had changed. Writing in 1969, political scientist Theodore Lowi observed that public policy had become about 'indemnifying damages rather than righting wrongs'. ${ }^{23}$ Ethnic and racial groups - now formal 'minorities' formulated critiques of American society that emphasized disadvantage, discrimination and above all difference. Federal policies, from bilingual education to affirmative action, catered to assertions of victimhood and minority rights and divided the nation into ethnoracial categories. White ethnic groups, following the black template, recognized the value of the ethnic group as a vehicle for asserting such claims. 'The Italian-American community has to make its move', the Italian newspaper Fra Noi explained in 1976. 'In a pluralistic society where many groups are grasping for public attention, public money and public approbation, the group which is most organized... has the best chance of capturing a legitimate voice in the making of public policy.' 'The Italian community is learning a lesson the black community learned long ago,' civil rights veteran Bayard Rustin observed admiringly. 'It is the squeaky wheel that gets greased.' ${ }^{24}$

The white ethnics did have genuine social and economic needs, and for some white ethnic mobilization was a necessary response to those needs. A study of Chicago's ethnic communities revealed that 83 per cent had no high school education and 65 per cent earned less than $\$ 10,000$ per year. ${ }^{25}$ However, unable to adapt their claims of economic disadvantage to the ethno-racial imperatives of anti-discrimination policy established by the minority rights revolution, ethnic activists now asserted a 'white ethnic' identity and status almost analogous to racial minorities as a means of getting ahead. 'People are having real problems making it', one activist acknowledged in 1970. 'Some do have an ethnic vision of themselves... that's one channel through which they 


\section{THE POLITICS OF WHITE ETHNICITY}

can organize to help themselves. ${ }^{26}$ This reassertion of white ethnic consciousness and group difference was thus not simply motivated by a fear of being left behind by organized racial minorities in the battle for scarce federal resources, but also a pragmatic response to the changing rules of the game in the American polity of the 1970s.

Other actors sensitized to the new white ethnic politics also responded to the concerns of the new era. Visions of a providential, unified national culture or community were questioned in the wake of liberalism's collapse, and white ethnic politics was a similar response. Many activists lamented a coercive immigrant experience - even analogising it to slavery - which had robbed ethnic Americans of their identity, culture, and heritage, and sought to use such a narrative as a means of building a shared sense of historical experience and solidarity amongst European ethnic groups. Baroni feared his Italian-American nephews and nieces would 'grow up like Wonder Bread - no crust, no identity'; Michael Novak, the leading intellectual voice in the white ethnic movement, argued that the white ethnics lacked the WASP 'sense of proprietorship about basic American symbols' or black students' knowledge that "black is beautiful", instead

facing 'cultural deprivation all along the line'. ${ }^{27}$ Others saw the resurgence of ethnicity as offering a new vision of national identity and community defined by group difference and diversity rather than universalism, filling the cultural space vacated by liberalism. In doing so, they formulated a model of multiculturalism, albeit mainly white and European, in which ethnic pluralism became an integral part of Americanism. This vision was reflected in the ethnic studies legislation passed by Congress in 1972 and the Bicentennial celebrations of 1976. 
Community organizations organized along pan-ethnic lines, replicating developments in black communities, also responded to the new environment. Whilst fraternal organizations for individual ethnic groups such as the Polish-American Congress and Sons of Italy had long existed, much of the white ethnic activism of the 1970s was defined by its attempts at multiethnic political mobilization. Democratic Senator Barbara Mikulski cut her political teeth organising the South East Community Organization (SECO) in ethnic Baltimore, where she led the fight against discriminatory disinvestment and 'redlining' in urban communities and developed NCUEA chapters for working-class ethnic women. Mikulski called for a 'new Agenda for America', built on an alliance between 'forgotten and forlorn' ethnic Americans and racial minorities 'based on mutual issues, interdependence and respect'. In Gary, Indiana, working-class ethnics united to form the Calumet Community Congress. The CCC featured in Newsweek and drew the attention of Senators Muskie and Kennedy, both of whom spoke out in praise of its pre-emption of racial conflict in the city and its pursuit of social and political reform. Both SECO and the CCC would secure six-figure grants for their work from the Ford Foundation and the federal government. ${ }^{28}$ In New York City, white ethnic activists transcended ethnic boundaries to establish the New York Center for Ethnic Affairs, with support from the Office of Economic Opportunity, Governor Nelson Rockefeller's State Division of Human Rights and a liberal city mayor, John Lindsay, keen to re-establish links with white ethnic communities and broaden the scope of anti-poverty projects. In its mission statement, the Center pledged, 'to lay the groundwork for cooperative efforts between New York's ethnic and minority populations on issues of mutual self-interest', and its Executive Director Ralph Perrotta used an op-ed piece in the New York Times to 


\section{THE POLITICS OF WHITE ETHNICITY}

call for a twin-pronged assault on the problems of poverty and racism and the inclusion of working-class ethnic whites in any future liberal or progressive political agenda. ${ }^{29}$

Each example adds greater complexity to our understanding of white ethnic politics, revealing it to be rather more diverse than previously assumed. Rather than pursuing wholly conservative ends, these organizations hint at the rather more complex, multifaceted, and often contradictory ideologies and intentions that lay behind white ethnic political mobilization in the late 1960s and early 1970s; more 'New Politics' than New Right. They reveal how white ethnic activists and organizations mobilized to confront the urban crisis and the threat of group polarization, seeking to build multiethnic coalitions on policy issues of mutual interest to both white and minority groups.

One such example of grassroots white ethnic mobilization came in Newark, New Jersey. Torn apart by rioting in 1967, Newark's problems were emblematic of the urban crisis gripping America's cities, pitting blacks and ethnic whites against one another in grim competition for scarce resources. Seventy five percent of the shrinking white population earned less than the average national income, and 13 per cent lived below the poverty line; locals bemoaned dilapidated schools, a divisive teachers strike, and violent crime. ${ }^{30}$ In the late 1960 s, news coverage focused on tensions (and sporadic violence) in the city between black militants and Italian-American councilman and backlash demagogue Anthony Imperiale, who talked of a coming race war and whose vigilante North Ward Citizens' Committee patrolled the streets warding off blacks from ethnic neighbourhoods. ${ }^{31}$

In the late 1960s, a group of Italian-Americans, dissatisfied with the Democratic machine of Mayor Hugh Addonizio and concerned about group relations in the city, 
formed the North Ward Educational and Cultural Center, offering programmes to help Italians gain work, college places, and access to anti-poverty programmes, even nominating candidates for political office. 'Blacks have got all these special programs to help them get to college... rehabilitate their houses or help them find jobs', revealed the Center's founder Stephen Adubato. 'We white ethnics don't get any of these things. All we want is equity.' 32

Yet despite his combative tone, Adubato was no advocate of racial backlash. Instead, he built links between the city's Italian and black communities, reflecting a keen political awareness of the changing demographics and power dynamics of American cities. In 1970 he supported the candidacy of Kenneth Gibson, Newark's first black mayor, much to the chagrin of Imperiale and his supporters (who labelled Adubato a 'nigger-lover' and accused him of 'treason'). Critical of a distant, unsympathetic liberalism, Adubato nonetheless spoke of his desire to build 'a new agenda [that] must include both groups [Italians and blacks]... a coalition whose objective is to build change', and reflecting the minority status attached to white ethnicity, he explicitly analogized Italians to blacks: 'People confuse us with the white Americans, which we're not. We're the working-class people who haven't made it in America, like the blacks, and we're still in the inner city... with them.' Adubato even described his organization, funded by money from the Ford Foundation and Rutgers University, as a 'white NAACP', servicing what he called 'the white ethnics... this country's largest minority group'.33

As with Baroni, Adubato's words underline forcefully the way in which Black Power and the minority rights revolution upended traditional forms of identity, 


\section{THE POLITICS OF WHITE ETHNICITY}

organization, and legitimacy in the political world of the 1970s. In stark contrast to previous decades, when Italians' 'not quite whiteness' was a political and cultural liability, it was suddenly politically advantageous within this new context to be a minority, and identities of racial whiteness lost traction in comparison.

Adubato may not have featured in as many national newspapers as Imperiale, nor provided such a convenient poster boy for the white ethnics-as-backlash narrative, but he proved far more adept politically, using a resurgent ethnicity to construct a political base in Italian neighbourhoods in the North Ward (distributing Italian flags and decals as campaign literature), winning support in both ethnic and black neighbourhoods, and building pan-racial political coalitions. In the municipal elections of 1971, over threequarters of Adubato's candidates won posts on the local Democratic Party committee in Newark, outmanoeuvring the Addonizio machine, and an Adubato-affiliated candidate defeated Imperiale himself to secure a council seat. ${ }^{34}$ Although his organization struggled to stem the exodus of middle-class whites from the city, Adubato broadened the reach of the North Ward Center to include non-white residents, many of them Puerto Rican, whilst continuing to address the needs of a diverse, multiethnic community. He would prove a major player in national white ethnic politics, serving on the board of both the NCUEA and Michael Novak's Ethnic Millions Political Action Committee (EMPAC) and acting as a consultant to the Ford Foundation on grants made to white ethnic projects and organizations. Whilst Imperiale's political career fizzled out, an abortive run for mayor of Newark in 1974 aside, Adubato was honoured by black, Puerto Rican and ItalianAmerican organizations for his work, and the North Ward Center lives on to this day. ${ }^{35}$ 


\section{JOE MERTON}

\section{III}

Once mobilized, the scope of white ethnic political activity during the 1970s was impressive. White ethnic organizations secured funding for their objectives from many liberal foundations and institutions typically associated with civil rights or anti-poverty causes. Prompted by ethnic activists such as Baroni and the American Jewish Committee's Irving Levine, both the Ford and Rockefeller Foundations saw the politics of white ethnic difference as a means of weaning ethnic communities away from racial backlash whilst also furthering black socio-economic advancement, a cause many perceived to have stalled in the 1970s. They subsequently provided six and seven-figure grants to projects such as the NCUEA and the AJC's National Project on Ethnic America. $^{36}$

Further funding and financial support also came from the Catholic church, where leaders, concerned about the precarious state of race relations, acknowledged its 'critical role to play in assisting white ethnic communities to better meet their needs'. The Church funded projects in Detroit (the Black-Polish Conference), Cleveland (Project Bridge and the Cleveland Ethnic Task Force) and Gary (Goals for Gary), each designed to improve group relations, tackle social problems, and train local organizers in racially-changing urban communities. Although the grants were small, the initial results were impressive. Observers praised the Black-Polish Conference for its success in depolarising the 1969 mayoral campaign in Detroit, and for defusing group tensions after the shooting of two Polish-American policemen outside a black nationalist meeting in the city. Goals for Gary was adopted by the city's first black mayor, Richard Hatcher, to involve the city's ethnic communities in proposals for economic and social development. ${ }^{37}$ 


\section{THE POLITICS OF WHITE ETHNICITY}

Having secured a viable financial base for their activities, white ethnic advocates built a sizeable lobbying presence in Washington. Organizations such as the NCUEA and EMPAC established offices in Washington; Novak outlining the latter's aim 'to raise public awareness... [of] ethnic issues... and to change public policies'. In Congress, Rep. Roman Pucinski and Senator Richard Schweiker led a successful bipartisan drive from 1969-71 to introduce federal legislation supporting ethnic studies programmes. Later, Reps. Frank Annunzio and Edward Derwinski led calls in the House for a White House Special Assistant for Ethnic Affairs, eventually introduced by Ford in 1975 and maintained by Carter. ${ }^{38}$ Many of these congressional advocates represented ethnic constituencies; others with more national ambitions, such as Kennedy, Muskie and Charles Percy, recognized the movement's political potential. Ethnic lobbies in Congress, traditionally oriented around the 'captive nations' and foreign policy issues, increasingly reflected social concerns, whilst attempts were made in the 1970 s to form both an ItalianAmerican and a specifically white ethnic congressional caucus - replicating similar organizations for blacks and Hispanics. ${ }^{39}$

With these structures in place, white ethnic activists could make an impressive impact on both local and national politics. Beginning with the introduction of a national Ethnic Heritage Studies Program in 1972, allocating \$8.3million of federal funds for ethnic studies, public policy increasingly recognized the legitimacy of claims to white ethnic entitlement. The Nixon administration pioneered Project Senior Ethnic Find, providing translation services, food stamps and other programmes to the low-income ethnic elderly, run by the federal volunteer agency ACTION. In Gary, Mayor Hatcher's staff believed the programme could correct perceptions of black entitlement amongst 


\section{JOE MERTON}

'Gary's minority - the white ethnic working people' - in a now black majority city. By the end of 1973, further programmes were proposed for Minneapolis, Milwaukee, and New York. ${ }^{40}$

Meanwhile, ethnic representatives in Congress and organizations such as the Sons of Italy successfully lobbied the Department of Health, Education and Welfare (HEW) to sponsor Italian bilingual education instruction in Brooklyn school districts in 1974. After further pressure, Jimmy Carter included Italian-Americans in new federal regulations on bilingual education during his presidency. ${ }^{41}$ White ethnic groups also successfully asserted their entitlement to affirmative action programmes in employment and education. In 1973, after concerted lobbying from white ethnic advocates in Congress, the Office of Federal Contract Compliance published regulations prohibiting discrimination against 'white ethnic minorities', whom, it acknowledged, 'continue to be excluded from executive, middle-management and other job levels because of discrimination based upon their... national origin'. Italian-Americans were designated as an affirmative action category at the City University of New York after a campaign by Italian-American organizations. And in 1976, the Midwest office of HUD extended affirmative action to Poles after research by the Polish-American Congress, supported by the NCUEA, revealed that only 10 percent of its employees were Polish, compared to a regional population twice that. ${ }^{42}$

Finally, the politics of white ethnicity cast an impressive shadow over national electoral politics during the 1970s. Traditionally, this impact has been assessed through Richard Nixon's 1972 election campaign, in which he welcomed ethnic voters into his Republican 'New Majority' through symbolic engagement with ethnic identity politics 


\section{THE POLITICS OF WHITE ETHNICITY}

and divisive appeals to urban whites over issues such as school busing, scatter-site housing and racial quotas. ${ }^{43}$ Yet again, the story is far more complex than that. As president Nixon met with Baroni and formulated a package of reforms, the Rosow Report, designed to broaden Great Society programmes to working-class Americans. Nixon's successor, Gerald Ford, appointed the first ever Special Assistant for Ethnic Affairs and hosted a series of White House conferences linking white ethnicity to public policy goals. And the Republican Party developed new organizational structures based around recognition of white, European ethnicity during the 1970s, using such identities as a means of political organization and mobilization designed to broaden the party's base in

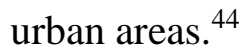

Far from being an exclusively Republican concern, the new ethnic politics was also of interest to the Democratic Party in the 1970s. First, leading figures within the white ethnic movement, including Baroni, Mikulski and Novak, were Democrats. And although challenged by younger, suburban 'New Democrats' elected in the landslide of 1974, many Democratic politicians and strategists saw great potential in the new ethnic politics. After controversies over the exclusion of traditional constituent groups from party reforms during the 1972 election, the Democrats' delegate selection committee, chaired by Mikulski, successfully finessed the issue of quotas, supporting the goals of the black, Hispanic and women's caucuses whilst reopening the party's doors to ethnic constituents. ${ }^{45}$ In New York, Lindsay's Democratic successor as mayor, Abe Beame, appointed individual liaisons to the Italian and Polish communities, as well as allocating city money for social programmes for marginal ethnic whites in the form of 'ethnic grants'. By mid-decade, the Democratic National Committee had investigated 


\section{JOE MERTON}

establishing a group to study legislation designed to help ethnic Americans, and had invited Novak to testify before the party's Platform Committee. ${ }^{46}$

Baroni's National Center for Urban Ethnic Affairs illuminates the character of white ethnic political activism during the decade. Outlining his 'White Urban Agenda', Baroni cited ethnics' common cause with racial minorities, their mutual problems of low income, educational underachievement and poor housing stock, and the need to counter such obstacles - as well as the threat posed by racial demagogues - with social reform. 'In too many areas, he concluded, 'the only people organising are hate-mongers' ${ }^{47}$

Like many white ethnic causes, Baroni found his ideas received a favourable hearing at the Ford Foundation. It provided start-up grants to the NCUEA worth over \$1million during 1970 alone, to initiatives in the areas of 'White Worker Discontent' and 'The Problems of Ethnic America', and community projects in Gary, Newark, Baltimore, and Detroit. In 1971, it joined the US Catholic Conference and AFL-CIO in helping the NCUEA open offices in Washington. Ethnic Americans were 'alienated... forgotten... troubled', the Foundation acknowledged. The grants would help 'develop a dialogue between the ethnic and black and brown communities... to bring these groups together... to find areas of common problems in order to engage in common programming, ${ }^{48}$

After arriving in Washington, Baroni continued to use the NCUEA as a means of raising consciousness of white ethnic interests in the nation's capital. He established an academic base at the Catholic University, and built links with national organizations, including the National Urban Coalition (with whom it delivered projects of 'blue-collar activities') and Common Cause. ${ }^{49}$ The NCUEA attracted many liberal Democrats keen to tap into the white ethnic constituency, including Kennedy, Muskie, and George 


\section{THE POLITICS OF WHITE ETHNICITY}

McGovern, who attended NCUEA conferences and lobbied Congress on behalf of white ethnic causes. ${ }^{50}$ And as outlined above, the NCUEA took its cause to the White House, Baroni meeting with Nixon in 1970 and Ford in 1976 to discuss the needs of urban ethnic communities.

The NCUEA placed itself at the heart of major liberal concerns of the era. In the area of women's rights, it sponsored the creation of the National Congress of Neighborhood Women, whose first conference brought together 150 women from ethnic communities to discuss grassroots organization, community activism and issues of childcare, housing and education. ${ }^{51}$ In the area of multiculturalism, Baroni successfully lobbied the federal government for the creation of the Bicentennial Ethnic Racial Council (BERC), which he chaired, to coordinate minority group participation in the nation's Bicentennial celebrations in 1976. Backed by White House funds, BERC championed America's multiethnic diversity in the Bicentennial themes and programmes it proposed - from the Smithsonian's 'Nation of Nations' exhibit to local street festivals nationwide and it had a lasting impact on ideas of national community. As chairman of Bicentennial planning John Warner concluded: 'We are a nation of nations, proud of the richness and diversity of our cultures; the Bicentennial marks the end of any thought of being a melting pot.' 52

The centrepiece of the NCUEA's policy activity was the issue of neighbourhood revitalization. Baroni and his team were convinced that if the urban crisis was to be averted, ethnically-distinct inner-city neighbourhoods, struggling against white flight, disinvestment and destructive urban renewal projects, had to be preserved. Federal urban policy had to make this a priority. 'No one is speaking for the neighbourhoods,' Baroni 


\section{JOE MERTON}

wrote in the Washington Post in June 1976, '[but] neighbourhoods are the key to the problems of the city. If the neighbourhoods die, the cities die.' But Baroni's embrace of the neighbourhood did not equate to blind resistance to racial integration. Instead, the NCUEA supported programmes to train a new cadre of progressive neighbourhood leaders and organizers, provided funding for local credit unions and fledgling neighbourhood development corporations, developed neighbourhood revitalization projects and actively combated redlining through involvement in the authorship of the 1977 Community Reinvestment Act. Democratic politicians ranging from Mayors Kevin White (Boston) and Kenneth Gibson (Newark) to Senators Muskie and William Proxmire endorsed NCUEA programmes aimed at neighbourhood revitalization, and asked for their constituencies to be considered as demonstration cities. And although Baroni supported the right of neighbourhoods to retain their ethnic distinctiveness, the neighbourhood movement was palpably multiracial, as blacks and whites united around the threat posed to inner-city communities. In 1976 the New York Times praised neighbourhood organizations backed by the NCUEA, such as Baltimore's SECO and Gary's CCC, as 'perhaps the most thoroughly integrated protest since the early civil rights days' ${ }^{53}$

The NCUEA made its urban policy breakthrough in 1976, with a White House conference on ethnicity and neighbourhood revitalization, overseen by President Ford and his new Special Assistant for Ethnic Affairs, Myron Kuropas. The conference, bringing together activists, politicians and representatives from the White House and federal departments, broke new ground in its emphasis on the fundamental difference of white ethnics and their entitlement to separate consideration in public policy. 'This day,' 


\section{THE POLITICS OF WHITE ETHNICITY}

Baroni declared, 'will provide the impetus for promoting the special programmes so important to ethnic America. ${ }^{54}$ But it was also successful in building a multiethnic coalition behind neighbourhood revitalization, including representatives from black and Hispanic communities, and stressed unity and togetherness, even a collective vision of national identity, through the recognition of group difference and multiculturalism. As Secretary of Commerce Elliot Richardson told participants, reflecting an evolving vision of Americanism as cultural pluralism, 'It is time now for us to forge a strategy based on coalition between diverse groups recognising each other's right in a pluralistic society to build a sense of community and ethnic pride.' Such optimism was further fuelled by Ford's creation of a Presidential Committee on Urban Development and Neighborhood Revitalization, the award of a two-year, \$474,000 HUD grant to the NCUEA to study neighbourhood development in major cities, and the primacy of issues of ethnicity and neighbourhood during the 1976 election, in which both candidates grappled to demonstrate their commitment to ethnic pluralism and the white ethnic agenda. ${ }^{55}$

\section{IV}

The politics of white ethnicity continued to wield considerable influence over President Jimmy Carter's Democratic administration towards the end of the 1970s, further evidence of its appeal to liberals and progressives, as well as conservatives, in a period of political flux. Against the backdrop of partisan 'dealignment' and weakened political institutions, Democrats also recognized the power of white ethnic assertion and the evident need to engage with it. Thus despite his pious eschewal, even denunciation, of interest group politics early in his administration, Carter recognized the potency of appeals to white 


\section{JOE MERTON}

ethnic identity politics, harnessing it to his attempts to return ethnic voters to the Democratic Party and rebuild a divided Democratic coalition. Designing a White House network of special representatives working with ethnic constituency groups, Carter continued and even expanded the institutionalization of ethnic group difference in government under Nixon and Ford, reinvigorating an older politics of ethnic pluralism upon which the old Democratic coalition had been based. ${ }^{56}$

Carter's new Office of Ethnic Affairs, catering to the needs of white, European ethnics and replicating similar mechanisms for racial minorities, was headed by the Italian-American Stephen Aiello. A former president of the New York City Board of Education, Aiello was convinced of the need to develop multiethnic coalitions, cutting across group lines, to build support for public policy. As board president, Aiello's successes included the development of a multicultural bilingual education programme in the city, offered to both minority and white ethnic groups, and his goals and rhetoric reflected the wider national trend towards cultural pluralism. 'We are all ethnics in the United States,' he declared in 1980. 'Americans live in a pluralistic society. It is essential to develop a public policy that reflects this pluralism. ${ }^{57}$ Such words would form part of an 'ethnic plank' in the Democratic Party platform for the 1980 presidential election campaign, which, underlining the progressive, multiculturalist tone of much of Carter's engagement with white ethnicity, reified America as 'a beautiful mosaic' and pledged to 'foster the concept of pluralism' in national politics and society. ${ }^{58}$

Indeed, whereas Richard Nixon had typically used white ethnic identity politics almost as a divisive wedge, designed to detach ethnic voters from the Democratic coalition, Carter's aides saw the accentuation of ethnic pluralism as a means of reducing 


\section{THE POLITICS OF WHITE ETHNICITY}

the group polarization that had proved so detrimental to the Democratic Party over the

previous decade. Recognising white ethnic entitlement to federal programmes and policy, they believed, would enable the administration to rebuild a fractured Democratic organization, reduce conflict over contested liberal programmes and correct a wider public perception of such initiatives as in thrall to organized interests. 'Our desire', Aiello stated, 'is to make the general society aware and responsive to the legitimate needs and aspirations of all ethnic groups... and not turn one group against the other., ${ }^{59}$

Thus Carter, declaring his 'need to address the problems of the ethnic poor' at a 1977 public policy forum, embraced the neighbourhood revitalization agenda championed by the NCUEA. Besides appointing Baroni as Assistant Secretary for Neighborhoods at HUD, his administration created a National Commission on Neighborhoods, staffed by activists and organizers from white ethnic and minority group communities, as part of its 1978 urban policy proposals, and granted $\$ 25$ million per year to neighbourhood organizations ${ }^{60}$ His administration encouraged the executive branch to include white ethnic groups in affirmative action regulations, whilst federal agencies were encouraged to explore shifting the definition of 'minority' from a racial term to a broader one reflecting socio-economic disadvantage. Aiello even investigated the possibility of a White House affirmative action policy specifically for ethnics. ${ }^{61}$ The administration also recommended that the definition of 'national origin' in Title VII of the Civil Rights Act be extended to include ethnic Americans, and sponsored a consultation on the 'Civil Rights Issues of Euro-Ethnic Americans in the United States' in December 1979, which ensured the Equal Employment Opportunity Commission issued new guidelines for discrimination based on national origin. Aiello later described 
the consultation as 'a first step... [making] Euro-ethnics feel that they are also part of what's happening with blacks and Hispanics and others when it comes to discrimination' ${ }^{62}$

However, Carter was engaging with a failing white ethnic politics, rapidly overwhelmed by a transformed political and socio-economic environment which by 1980 favoured a broader rightward shift in national politics. Such a swing proved fatal to the liberal aspects of white ethnicity. Carter's embrace of ethnic identity politics contradicted his own political rhetoric, exacerbated group tensions within a disintegrating Democratic coalition, and was identified by the public with an unpopular interest group liberalism and perceived sense of national fragmentation at the end of the 1970s. The politics of white ethnicity's failure to transcend those fears ensured it became regarded as a symptom of, rather than an antidote to, this crisis. Identity politics, only a few years earlier recognized as a political necessity for ethnic groups, with the black civil rights movement as its moral and political exemplar, was now regarded as a pejorative epithet, a byword for selfishness, division and fragmentation. Ethnic newspapers such as the Greek language Ethnikon, previously enthusiastic converts to white ethnic identity politics, now called on political leaders 'to restore the unity of America'. And in the Carter White House, Aiello found himself responding to letters, many from ethnic Americans, condemning the creation of an Office of Ethnic Affairs for cultivating divisiveness and polarization. ${ }^{63}$ Transcending these divisions through a renewed universalist language that harked back to the post-war era of ethnic assimilation, Republican Ronald Reagan was able to appeal more effectively to ethnic voters concerned about non-ethnic, middle class issues such as inflation, taxes and declining national prestige. 


\section{THE POLITICS OF WHITE ETHNICITY}

Likewise, tightening economic constraints, notably the runaway inflation of the 1979-80, rendered large federal outlays on liberal programmes specifically for ethnics unlikely (although they had rarely ever risen above tokenism) and diminished many nongovernmental sources of funding. The neighbourhood revitalization agenda Baroni was appointed to deliver was one such victim of this new fiscal austerity, swallowed up, along with the administration's wider urban policy proposals, by Carter's fiscal conservatism. ${ }^{64}$ Such constraints also reasserted identities of class amongst ethnics, breeding a new middle-class consciousness of conservative bent that viewed liberal government as inimical to their own interests, railed against 'handouts' and 'giveaway programmes' and rendered support for a politics of compensatory justice and ethnic identity increasingly untenable. ${ }^{65}$ Indeed, ongoing socio-economic trends, underlined by the 1980 US Census, revealed that the minority rights agenda propagated by liberal ethnic activists targeted an ethnic community that was increasingly middle-class, suburban, and difficult to locate. ${ }^{66}$ Despite the economic insecurities of the late 1970s, the increasingly assimilated, upwardly mobile majority took little sustenance from a white ethnic agenda of minority group entitlement and recognition that sought redress for grievances the majority of them barely felt and pursued rights and programmes they pejoratively associated with minorities and the poor. Sociologist Andrew Greeley, an early advocate for the white ethnics, affirmed that compared to blacks or Hispanics, 'the pain was [not] enough to create a genuine social movement' for ethnics. ${ }^{67}$

Finally, white ethnic politics was never able to overcome its own institutional shortcomings. Despite the feverish attention it received, the white ethnic movement, as such, was never a grassroots phenomenon. Outside of Washington, few ethnic Americans 
JOE MERTON

identified themselves as underprivileged white ethnics; few of them, when interviewed by sociologists, had even heard of the new politics of white ethnicity. Attempts at multiethnic political mobilization and engagement were not always successful, and traditionally powerful and well-resourced individual ethnic groups, notably ItalianAmericans, continued to dominate the agenda, often championing individual national group concerns over interethnic ones. Indeed, the diversity of white ethnic interests was more a weakness than a strength, inhibiting group unity and cohesion. Instead, 'white ethnic' was primarily a label appropriated on these groups' behalf either by the activists and intellectuals who promoted it, or the politicians who glimpsed its potential. In truth, Baroni and his contemporaries remained leaders without followers. 'There was an awful lot of smoke and mirrors about the ethnic movement', Greeley ruefully concluded. 'It was not much ado about nothing, but some ado about practically nothing. ${ }^{68}$

\section{$\mathbf{V}$}

The politics of white ethnicity was rather more complex and diverse than is traditionally outlined by historians. The inclination to present them as racist reactionaries or obstructionists accentuates the most visceral expressions of political ethnicity, at the expense of the work of activists such as Mikulski, Baroni, or Adubato in developing a more temperate, substantive white ethnic politics. It overlooks the role played by the recognition of white ethnic difference in building coalitions over neighbourhood revitalization, the Bicentennial celebrations or Project Senior Ethnic Find, and its attentiveness to the pressing social needs of many urban ethnic communities. It was by no means, to quote two recent historians on the subject, solely an 'atavistic cultural 


\section{THE POLITICS OF WHITE ETHNICITY}

populism' targeted at racial resentments, but in many cases sought to actively counter such sentiments after the tumult of the 1960s. ${ }^{69}$

Equally, rather than directly encouraging a conservative shift during the 1970s amongst ethnic Americans, white ethnicity in fact held potential for both conservatives and liberals, reflecting a decade defined by political flux, in which conventional categories of left and right, liberal and conservative, did not always hold fast. White ethnic politics was a heterogeneous impulse with a diverse range of objectives and concerns, and in different ways, both right and left called on it to construct political coalitions. Likewise, at the grassroots, white ethnicity was not only represented by angry exponents of racial backlash but also campaigners for social reform. Thus white ethnicity was more than a staging post in the conservative resurgence of the late twentieth century, but a powerful manifestation of an era of political void, even drift.

So why the distortion? One reason for this oversight may be the problems engendered by a top-down, executive-led approach. By focusing on the divisive strategising of a president such as Nixon, who tended - at least after his first year in office - to theorize the white ethnics as angry backlashers, appealed to through coarse appeals to social grievances, historians have left us with a warped image of the white ethnic constituency. For Nixon, ethnic communities' defence of their neighbourhoods equated to assaults on racially redistributive policies such as school busing and open housing; an interpretation historians have largely bought into. At the grassroots, where neighbourhood activism carried a very different definition to Nixon's, there was a remarkably different picture. 


\section{JOE MERTON}

Another reason may be the fact that the examples of white ethnic political activity discussed above, from successful applications for Ford Foundation monies to the lobbying of politicians, were simply not as viscerally exciting as Irish and ItalianAmerican anti-busing protesters in Boston, nor Anthony Imperiale's vigilantes in Newark. Nevertheless, they were as real, substantive, and important, if not more so, and possessed great influence on national politics during the 1970s. The white ethnics knew they had to follow the template laid out by racial minorities during the 1960s.

The distortion may also lie in scholars' tendency to look for linear patterns in the volatile political environment of the 1970s. Certainly, scholars are correct to identify ethnic voters' traditional allegiance to the Democrats as losing its vitality during this period; election returns reveal as much. ${ }^{70}$ And there is much evidence to suggest that there was a broader rightward shift abroad in the nation by 1980 . However, whether the white ethnic politics of the 1970s fits into this narrative of conservative renaissance is debatable. Many non-ethnic factors influenced ethnic political behaviour, from the economy to the changing composition of the political parties. Identities of class, race, and religion often transcended those of ethnicity or national origin at the polls. The white ethnic agenda reflected many of these constituent factors, identities, and concerns, each huddled under the 'white ethnic' umbrella. And the goals and politics practiced by ethnic activists during the 1970s had little in common with the substance and rhetoric of the Reagan revolution; instead they seem to step from another era.

This article has sought to reshape both our understanding of the politics of white ethnicity and, more generally, the political character of 1970s America. By providing a broader and fuller portrait of the nature of white ethnic political activism, focusing on the 


\section{THE POLITICS OF WHITE ETHNICITY}

grassroots as well as the executive, the failure of white ethnic identity politics as well as its emergence, we can see that in many ways, the 1970s were not the conservative 1970s, but a period of considerable uncertainty and sudden transition. This does not make the decade a time of political disengagement and inactivity; a time when 'it seemed like nothing happened' ${ }^{71}$ Instead, the 1970 s were a period of great political experimentation and volatility, in which traditional political and cultural norms, values, and institutions were weakened or challenged. Political alternatives such as the white ethnics took succour from the staggering impact of the black civil rights revolution and the surprisingly persistent legacy of the 1960s on the political world of the 1970s, whilst responding to the transformative environment of the new era. Even if they were eventually unsuccessful, their attempts to develop a viable post-liberal, yet not conservative, politics are important. Therefore, perhaps we should rethink what we know not only about the politics of white ethnicity, but also the 1970s.

The largely untold stories of white ethnic political activism outlined above further underline the point. They reveal how political actors of all backgrounds, unable to divine the trajectory of their times during the 1970s, sought to engage with the new ethnic politics, and utilize it for their own, often divergent, ends. These actors, scrambling for new ideas in the absence of a prevailing post-liberal wisdom, keen to build new coalitions and seduced by white ethnicity's protean meanings, assigned it great agency and potential power. And once drawn to white ethnicity, they often imposed their own, competing notions and meanings of white ethnicity upon the label itself. Therefore, white ethnics could be conservatives, as theorized by Richard Nixon, but they could also be liberals and progressives, actively combating racial backlash. 
JOE MERTON

Such heterogeneity reflects the shortcomings of the existing tendency to portray the white ethnics as an element in the conservative counterrevolution of the late twentieth century. Instead, the politics of white ethnicity was a powerful manifestation of a decade of political vacuum; a transitional or 'bridge' period defined by the abrupt end to the certainties of the liberal consensus, but not yet ready to embrace conservatism; a time when the nation stood rather awkwardly between the rigid post-war ideals of ethnic assimilation and the present-day reality of fluid, self-prescribed ethnic affiliations for European ethnic whites. An appreciation of this point gives us a broader, more representative understanding of white ethnic politics, emphasising its essential ambiguity, malleability and consequent appeal to groups from across the political spectrum. It highlights white ethnicity's significance in the wider reformation of American politics that took place after the achievements of the civil rights revolution. It underscores the shortcomings of the white ethnic assertion of the 1970s for our understanding of the rise of conservatism. Finally, it might also enable us to come to a more accurate, if decidedly less linear and straightforward, portrait of the 1970s, underlining the volatile, complex character of this chapter in American history and its significance for the formation of ethnic identities in today's 'post-ethnic' United States. ${ }^{72}$

Dr Joe Merton, Department of History, University of Nottingham, University Park, Nottingham, NG7 2RD. Email: joe.merton@nottingham.ac.uk

${ }^{1}$ Washington Post (WP), 16 Apr 1977, p. E1; New York Times (NYT), 20 Apr 1977, p. 48.

21970 Labor Day Statement, 4 Sept 1970, ‘1970 News Clippings (Ethnicity),' Box 3/29, National Center for Urban Ethnic Affairs (NCUEA) Papers, University of Notre Dame 
Archives, South Bend, In; Baroni qu. in Lawrence O’Rourke, Geno (Mahwah, 1991), pp. $76-7$.

${ }^{3}$ Geno Baroni, 'Ethnicity and public policy,' in Michael Wenk et al, eds., Pieces of a dream (New York, 1972), pp. 8-11; Baroni quoted in Arthur Mann, The one and the many (Chicago, 1979), p. 34. Likewise, Michael Novak, the intellectual figurehead of the white ethnics, hypothesized a black- ethnic alliance as 'the one inevitable, fundamental, indispensable coalition.' See Novak, The rise of the unmeltable ethnics (New York, 1971), pp. 249-57.

${ }^{4}$ WP 1 June 1969, p. 190. For further examples of national press coverage of Baroni's activities, see Newsweek, 21 Dec 1970, p. 30; NYT, 17 June 1970, p. 49; Ibid., 27 Nov 1970, p. 41; Ibid., 16 Mar 1972, p. 49; Ibid., 9 May 1976, p. 177; WP, 13 July 1970, p. A22; Ibid., 27 May 1972, p. A16; Ibid., 30 June 1976, p. A19.

${ }^{5}$ Memo for the President, Meeting with Monsignor Geno Baroni, 17 Aug 1970, Box 82, Charles W. Colson Files, White House Special Files (WHSF), Staff Member and Office Files (SMOF), Nixon Presidential Materials Project (NPMP), National Archives, College Park, Md.

${ }^{6}$ O’Rourke, Geno, p. 133.

${ }^{7}$ Newsweek, 21 Dec 1970, p. 30.

${ }^{8}$ Edward Berkowitz, Something happened (New York, 2006), pp. 205-08; Matthew Jacobson, Roots too (Cambridge, 2006), pp. 72-129, Bruce Schulman, The seventies (New York, 2001), pp. 83-4; Donna Gabaccia, We are what we eat (Cambridge, 1998).

${ }^{9}$ Deac quoted in Newsweek, 6 Oct 1969, pp. 20-38. 
${ }^{10}$ Ronald Formisano, Boston against busing (Chapel Hill, 1991), pp. 3, 236-8; Orlando Patterson, Ethnic chauvinism (New York, 1977), pp. 158-85. For works that place race and racial backlash at the centre of the conservative revival during the 1960s and 1970s, see Dan Carter, From George Wallace to Newt Gingrich (Baton Rouge, 1996), Dennis Deslippe, 'Do whites have rights?', Journal of American History, 91 (2004), pp. 932-60, Thomas Edsall \& Mary Edsall, Chain reaction (New York, 1991), Matthew Lassiter, The silent majority (Princeton, 2006), Kevin Kruse, White flight (Princeton, 2005), and Jonathan Rieder, Canarsie (Cambridge, 1985). Thomas Sugrue, The origins of the urban crisis (Princeton, 1996), takes the story back even further to the years following World War II, when the embrace of white racial privilege became an important tool of ethnic assimilation. For the 'Reagan Democrats', see Stanley Greenberg, Middle class dreams (New Haven, 1996).

${ }^{11}$ Mary Waters, Ethnic options (Berkeley, 1990), p. 157; Jacobson, Roots too, pp. 8-9, 177-205; Robert Mason, Richard Nixon and the quest for a new majority (Chapel Hill, 2004), pp. 98-9, 168-69; Thomas Sugrue \& John Skrentny, 'The white ethnic strategy,' in Bruce Schulman \& Julian Zelizer, eds., Rightward bound (Cambridge, 2008), pp. 171-92. ${ }^{12}$ The assumption of this 'not-quite-white' identity queries the implicit certainties of much of the historical literature on ethnic 'whiteness', which suggests the existence of a rigid framework of ethnic and racial distinctions and a white racial identity that, upon its assumption by European immigrants in the early twentieth century, remained irrevocably locked in place, securing ethnic group assimilation. For examples, see Sugrue, Origins; Arnold Hirsch, Making the second ghetto (Cambridge, 1983); Matthew Jacobson, Whiteness of a different color (Cambridge, 1998); David Roediger, The wages of 
whiteness (London, 1991); Jennifer Guglielmo \& Salvatore Salerno, eds., Are Italians white? (New York, 2003); Thomas Guglielmo, White on arrival (Cambridge, 2003). ${ }^{13}$ The notion that a liberal alternative did exist in the 1970s, only to founder on the lack of effective political leadership, has enjoyed something of a historiographical renaissance in recent years. For examples, see Timothy Stanley, Kennedy vs. Carter (Lawrence, 2010), and essays by Gareth Davies, Stephen Tuck, Simon Hall and Joshua Zeitz in Journal of Contemporary History 43 (2008), pp. 617-700. Likewise, this article acknowledges the persistence and vitality of some forms of liberal political activism, if also the potential limitations of labels such as 'liberal' and 'conservative', in the white ethnic politics of the 1970s.

${ }^{14}$ Nancy Seifer to Tom Morgan, 17 June 1971, 'Workshop: New Directions for Urban America,' Box 2/40, NCUEA Papers.

${ }^{15}$ NYT, 16 Mar 1972, p. 49; Italo-American Times, July 1972, from Italian-American Periodicals Collection, Immigration History Research Center (IHRC), University of Minnesota, Minneapolis, Mn.

${ }^{16}$ Will Herberg, Protestant, catholic, jew (New York, 1955), pp. 33-6, 45-53; Nathan Glazer \& Daniel Patrick Moynihan, Beyond the melting pot, $1^{\text {st }}$ edn (Cambridge, 1963), p. 315; Commonweal, 9 Dec 1966.

${ }^{17}$ Michael Flamm, Law and order (New York, 2005), p. 81; James Patterson, Grand expectations (New York, 1996), p. 708; NORC poll, reproduced in Andrew Greeley, Why can't they be like us? (New York, 1975), p. 210; Norman Nie et al, 'Political Attitudes Among White Ethnics', Ethnicity, 1 (1974), pp. 317-44. 
${ }^{18}$ On the decline of Democratic machines, see Alan Ware, The breakdown of Democratic Party organization, 1940-1980 (Oxford, 1985); Steven Erie, Rainbow's end (Berkeley, 1988), pp. 170-87; Joshua Zeitz, White ethnic New York (Chapel Hill, 2007), pp. 172-6. On the emergence of a new ethno-cultural politics, see Richard Scammon \& Benjamin Wattenberg, The real majority (New York, 1970), pp. 35-71; Byron Shafer \& William Claggett, The two majorities (Baltimore, 1995).

${ }^{19}$ For example, the annual budget of the Polish-American Congress fell from $\$ 305,000$ in 1948 to under $\$ 40,000$ by the 1970 s. By 1982 , only $7 \%$ of Polish-Americans belonged to a fraternal organization. See Donald Pienkos, 'Polish-American Ethnicity', in Joseph Roucek \& Bernard Eisenberg, eds., America's ethnic politics (Westport, 1982), pp. 2856; John Bukowczyk, And my children did not know me (Bloomington, 1987), pp. 123-4.

${ }^{20}$ NCUEA Annual Report, 1974, 'NCUEA: Report of Activities, Jan 1976-Jan-1977,' Box 50/36, NCUEA Papers.

${ }^{21}$ John Skrentny, The minority rights revolution (Cambridge, 2002).

${ }^{22}$ For the classic exposition of this ideal, see Gunnar Myrdal, An American dilemma (New York, 1944). For Martin Luther King's faith in universalism and citizenship, see Gary Gerstle, American crucible (Princeton, 2000), pp. 272-7. On this strategy pursued by Mexican-Americans, see Lorena Oropeza, Raza si! guerra no! (Berkeley, 2005), pp. $11-46$.

${ }^{23}$ Theodore Lowi, The end of liberalism (New York, 1969), p. 213.

${ }^{24}$ Fra Noi, Jan 1976, from Italian-American Periodicals Collection, IHRC; Rustin qu. in NYT, 6 Feb 1975, p. 29. 
${ }^{25}$ Thomas Pavlak, 'Social class, ethnicity and racial prejudice', Public Opinion Quarterly, 37 (1973), p. 227.

${ }^{26}$ WP, 18 June 1970, p. 1.

${ }^{27}$ NYT, 30 Dec 1979, p. DX6; US News \& World Report, 14 Oct 1974, pp. 46-8.

${ }^{28}$ Kenneth Durr, Behind the backlash (Chapel Hill, 2003), pp. 161-76; NYT, 29 Sept 1970, p. 43; Newsweek, 21 Dec 1970, p. 30.

${ }^{29}$ NYT, 3 Sept 1972, p. 1; Dominic Massaro to Jack Sable, 19 Nov 1971, in Folder 'New York State Division of Human Rights, Italian Conference, 1971', Box 45, Dominic Massaro Papers, IHRC; Mission Statement, The New York Center for Ethnic Affairs, 1972, in Folder 'New York Center for Ethnic Affairs, 1970-77,' Box 33, Ibid.; NYT, 14 Dec 1972, p. 47.

${ }^{30}$ Thomas Brooks, 'Breakdown in Newark', Dissent (Winter 1972), pp. 128-37.

${ }^{31}$ NYT, 26 Aug 1968, p. 33; Ibid., 29 Sept 1968, p. SM30; Newsweek, 6 Oct 1969, p. 65. ${ }^{32}$ NYT, 28 Aug 1971, p. 27.

${ }^{33}$ Richard Krickus, 'Organizing neighborhoods,' Dissent (Winter 1972), pp. 107-17;

Brooks, ‘Breakdown', pp. 136-7; NYT, 28 Aug 1971, p. 27; Ibid., 4 May 1973, p. 79;

Ibid., 27 July 1975, p. 50.

${ }^{34}$ Brooks, ‘Breakdown'; NYT, 28 Aug 1971, p. 27.

${ }^{35}$ The North Ward Center Inc., <http://www.northwardcenter.org/>.

${ }^{36}$ Letter, Irving Levine to Basil Whiting, 6 Dec 1969, PA 71-69, Ford Foundation Archives, New York, N.Y.; Program Action Form, n.d., PA 71-69, Ibid.; Program Action Form, n.d., PA 710-0070, Ibid. 
${ }^{37}$ USCC Task Force on Urban Problems, Ethnos - bulletin on white ethnic communities in pluralistic urban America, June 1970, 'Urban Ethnic Community Development Workshop', Box 38/10, Papers of Geno C. Baroni, University of Notre Dame Archives; Perry Weed, The white ethnic movement and ethnic politics (New York, 1973), p. 110.

${ }^{38}$ Letter, Novak to Kahn, Apr 1975, Folder 7, Box 9, Records of EMPAC (Ethnic Millions Political Action Committee), Balch Institute for Ethnic Studies, Philadelphia, Pa.; Congressional Record, 13 Nov 1969, p. 34,165, 20 Nov 1969, p. 35,435, and 26 Jan 1971, pp. 544-45; Ibid., 10 Mar 1975, p. 5903; Letter, Baroni to Annunzio, 15 Apr 1975, 'Correspondence: Legislative Branch - Baroni', Box 61/04, NCUEA Papers; Novak correspondence in Folder 1, Box 6, EMPAC Records.

${ }^{39}$ Remarks of Joseph Vaghi before American-Italian Congressional Delegation, Washington D.C., 6 May 1975, Folder 2, Box 126, National Italian-American Foundation (NIAF) Records, IHRC; Letter, Michael Novak to Mario Biaggi, n.d., Folder 7, Box 6, EMPAC Records.

${ }^{40}$ Carole Baker to James Holland, 2 Oct 1972, 'Gary', Box 13, Myron B. Kuropas Files, Gerald R. Ford Presidential Library (GFL), Ann Arbor, Mich.; GOP Nationalities News, Vol. 5 (1) (Jan-Feb 1975), copy in 'Republican National Committee (1)', Box 53, Theodore C. Marrs Files, GFL.

${ }^{41}$ NYT, 26 Apr 1974, p. 14; Mission Statement, New York State Order of Sons Of Italy in America Education Committee, n.d., 'Education Committee, 1973-80,' Box 17, Order of the Sons of Italy in America - New York State Grand Lodge Papers, IHRC; Esteban Torres to Jack Watson, 28 July 1980, 'Education, Department of 11/79-4/80,' Box 2, Stephen Aiello Files, Jimmy Carter Library (JCL), Atlanta, Ga. 
${ }^{42}$ Business \& Society Review, No. 8 (Winter 1973-74), pp. 37-41; 'Guidelines on Discrimination Because of Religion or National Origin', reprinted from Federal Register, Vol. 38, No. 13, 19 Jan 1973, copy in author's collection; Report of the Commission on Bias, Bigotry and Prejudice of the Grand Lodge of the State of New York, June 1978, 'Discrimination at CUNY, 1978', Box 16, OSIA - NY State Grand Lodge Papers; Howard Stein \& Robert Hill, The ethnic imperative (University Park, 1977), pp. 263-64. ${ }^{43}$ Joe Merton, 'The politics of symbolism', European Journal of American Culture, 26 (2007), pp. 181-98; Sugrue \& Skrentny, 'White ethnic'.

${ }^{44}$ Joe Merton, "'The Republican Party is truly the party of the open door": ethnics and the Republican Party in the 1970s', in Iwan Morgan \& Robert Mason, eds., Seeking a new majority (Nashville, forthcoming).

${ }^{45}$ The Democratic reforms had introduced quotas for women, minorities and younger voters, but diminished the influence of the old ethnic party regulars. As journalist Mike Royko proclaimed upon the expulsion of Mayor Daley's Illinois delegation from the 1972 convention, '[the] reforms have disenfranchised Chicago's white ethnic Democrats.' For the Royko quote, see Chicago Daily News, 6 July 1972, copy in Box 21, Mike Royko Papers, Newberry Library, Chicago, Ill. For more on the reforms' disastrous effect on the Democratic loyalties of ethnic voters, see Bruce Miroff, The liberals' moment (Lawrence, 2007), pp. 189-194; Richard Krickus, Pursuing the American dream (Garden City, N.Y., 1976), pp. 242-250. For the Mikulski Commission and the finessing of the quotas issue in 1973, see WP, 31 Oct 1973, p. A22; Mikulski Commission, Democrats all (Washington, D.C., 1973). 
${ }^{46}$ NYT, 7 Oct 1974, p. 1; Democratic Party correspondence in Box 8, Folder 3, EMPAC Records.

47 'The Rationale for a White Urban Agenda', n.d., 'Rationale for a White Urban Agenda', Box 23/46, NCUEA Papers.

${ }^{48}$ Basil Whiting, 'The Suddenly Remembered American', Sept 1970, Report \# 002098, Ford Foundation Archives; ‘Request for Grant Action’, 16 Oct 1972, PA 73-030, Ibid.

${ }^{49}$ M. Carl Holman, National Urban Coalition, to Steering Committee, 11 Jan 1971, Box 176, National Conference of Catholic Charities/Catholic Charities US Records, American Catholic History Research Center and University Archives, Catholic University of America, Washington D.C. Both organizations had long been with identified with liberal causes, the National Urban Coalition as an advocate for minority group interests, and Common Cause a good-government, anti-corruption group.

${ }^{50}$ Weed, White ethnic, pp. 27-38.

${ }^{51}$ National Congress of Neighborhood Women Steering Committee to Conference Participants, 1 Oct 1974, 'Workshop: National Congress of Neighborhood Women, 10/18-20/74', Box 2/31, NCUEA Papers; Report on the Planning Session for a Women's Agenda, Washington DC, June 5-6 1973, in Ibid.

52 'National Bicentennial Ethnic Racial Council Conference Report', 20-22 Jan 1975, 'BERC', Box 87/24, NCUEA Papers; American Revolution Bicentennial Commission, The Bicentennial of the United States of America (Washington, D.C., 1977), p. 131.

${ }^{53}$ WP, 30 June 1976, pA19; National Center for Urban Ethnic Affairs list of 'Neighborhood Action Programs', n.d., 'Carter - Ethnics', Box 64/03, NCUEA Papers; 
Letters from Mayor Kevin White (and various) to Baroni, 13 Aug 1974, in Box 2, NCUEA Records, Balch Institute; NYT, 9 May 1976, p. 177.

${ }^{54}$ Ethnicity and Neighborhood Revitalization Conference Proceedings, 5 May 1976, 'Final Report of the Special Assistant for Ethnic Affairs (2)', Box 55, William J. Baroody Papers, GFL.

${ }^{55}$ Ibid.; NYT, 12 Oct 1976, p. 25. Ford aides (and even Ford himself) often spoke of an Americanism defined by ethnic pluralism and the United States as a 'mosaic', whilst a position paper drawn up at the neighbourhoods conference declared, 'In this bicentennial year we must develop a new vision of the American dream that brings us together, not in an untenable "melting pot" tradition, but in a spirit of "participatory pluralism".' See 'Ethnicity and Neighborhood Revitalization Conference Proceedings'; Position Paper, 'Neighborhood Policy for a Pluralistic Urban Society', 'Final Report of the Special Assistant for Ethnic Affairs (2)', Box 55, Baroody Files.

${ }^{56}$ In 1978 Carter had told an audience of Hispanic journalists, 'I wouldn't bring anybody on board to take care of a particular constituency group... it would just be contrary to what I want.' See Q\&A Session with the Hispanic Media, 12 May 1978, from The American Presidency Project, http://www.presidency.ucsb.edu; Karen Hult \& Charles Walcott, Empowering the white house (Lawrence, 2004), pp. 95, 100-02.

57 Author's interview with Stephen Aiello, New York City, 19 Mar 2008; White House Office of Ethnic Affairs News, June 1980, copy in author's collection.

581980 Democratic Party platform, from The American Presidency Project, http://www.presidency.ucsb.edu/showplatforms.php?platindex=D1980. 
${ }^{59}$ Tom Belford to Special Assistants, 23 July 1980, 'Special Assistants Coordination, 6/16/80 - 10/9/80,' Box 133, Landon Butler Files, JCL, emphasis in original.

${ }^{60}$ Remarks at a Q\&A session at Community Services Administration Public Policy Forum, 21 Oct 1977, from The American Presidency Project, http://www.presidency.ucsb.edu; Minutes, White House Meeting of Neighborhood and Community Organizations, 21 Dec 1977, Box 3, NCUEA Records, Balch Institute. For more on Baroni's experiences at HUD, see O'Rourke, Geno, pp. 136-70.

${ }^{61}$ Butler and Belford to Jordan, 16 May 1980, 'Special Assistants' Reports, 1980 [CF, O/A 647],' Box 55, Hamilton Jordan Files, JCL; NYT, 30 July 1978, p. 1; Aiello to Rubenstein, 27 Feb 1980, 'Chron File 1/80 - 2/80,' Box 16, Aiello Files.

${ }^{62}$ Aiello to David Rubenstein, undated, 'Affirmative Action 2/80 - 10/80,' Box 1, Aiello Files; Draft Executive Order on Including Ethnic Americans in the Processes of Government and Affirmative Action Efforts, n.d., 'Affirmative Action - Executive Order on Ethnic Americans 1/80 - 5/80,' Box 18, Ibid.; Platform Plank, 'Including Ethnic Americans in the Process of Government and Affirmative Action Efforts,' Box 1, Ibid.; Agenda, 'Civil Rights Issues of Euro-Ethnic Americans in the United States:

Opportunities and Challenges,' consultation sponsored by the US Commission on Civil Rights, 3-4 Dec 1979, ‘[Civil Rights Issues: Ethnics] 12/79,' Box 21, Ibid.; Stephen Aiello Exit Interview, JCL.

${ }^{63}$ Ethnikon, 30 Oct 1980, Ethnikon microfilm, Balch Institute; Letter, Aiello to Ms Brett Topping, 29 Aug 1980, 'Groups [Combinations of Ethnics] 3/80-10/80,' Box 4, Aiello Files; Letter, James Taylor, President of La Societa Di Cultura Italiana, to Carter, 10 May 1980, 'Italian: Correspondence 4/80- 5/80,' Box 14, Ibid. 
64 Thomas Sugrue, 'Carter's Urban Policy Crisis', in Gary Fink \& Hugh Davis Graham, eds., The Carter presidency (Lawrence, 1998), pp. 137-57.

${ }^{65}$ A 1977 National Italian-American Foundation study found that ethnic identification decreased significantly as Italian-Americans entered the middle class. See 'Formulating a National Italian-American Agenda,' Report and Analysis of the NIAF Survey of ItalianAmericans, Sept-Nov 1977, '1978 - Activities,' Box 28, NIAF Records. For the implications for liberalism, see Edsall \& Edsall, Chain reaction, pp. 105-7, 134-6.

${ }^{66}$ On the white ethnic success story, see United States Commission on Civil Rights, The economic status of Americans of southern and eastern European ancestry (Washington DC, 1986), pp. 1-5; HEW Office of Research and Statistics report, 'The Status of ItalianAmerican Families', 1977, in Folder 11, 'The Status of Italian-American Families,' Box 124, NIAF Records; Richard Alba, 'The Twilight of Ethnicity Among American Catholics of European Ancestry', Annals, 454 (1981), pp. 86-97.

${ }^{67}$ Author's interview with Andrew Greeley, Chicago, 25 Sept 2008.

${ }^{68}$ Mann, One, pp. 37-40; Stein \& Hill, Ethnic imperative, p. 166; Greeley interview.

${ }^{69}$ Skrentny \& Sugrue, 'White ethnic', p. 175.

${ }^{70}$ John Petrocik, Party coalitions (Chicago, 1981), pp. 82-3.

${ }^{71}$ Peter Carroll, It seemed like nothing happened (New Brunswick, 1990).

72 David Hollinger, Post-ethnic America (New York, 2000). 